\title{
Waving Web in Tourism Higher Education-Case Study at Tourism School of GUBS
}

\author{
Xuan Xiao, Jianhua Wu \\ Tourism School, Guangdong University of Business Studies, Guangzhou, China \\ Email: adelaxiao@126.com
}

Received August $6^{\text {th }}, 2012$; revised September $10^{\text {th }}, 2012$; accepted September $18^{\text {th }}, 2012$

\begin{abstract}
Purpose: The purpose of this paper is to introduce some approaches to wave web in tourism higher education, with analyses on key successful factors. Design/methodology/approach-The methods of investigation used in this study include observation, in-depth interviews, survey and secondary data. Findings: A comparison study indicates that virtual learning environment is a good solution to massive course load in tourism higher education. The paper figures out three effective approaches based on Blackboard System, and KSFs of online implementation, such as instructor preparation, course development, instructor accessibility, course monitoring and technology support. Originality/Value: This paper illustrates the contribution of computer aided instruction and virtual learning environment to tourism higher education through case study.
\end{abstract}

Keywords: Online Education; Tourism Higher Education; Approaches; Key Successful Factors; Case Study

Online education in mainland China was initiated in 1990s, and the market has witnesses a remarkable annual growth of about 20\% since 2004. In 2009, online education achieved a market size of RMB 45.6 billion (US\$7.15 billion) and 20 million registered users, with higher education accounted for over $80 \%{ }^{1}$. This paper is to introduce some approaches to wave web in tourism higher education, with analyses on key successful factors, through a case study of Tourism School of GUBS.

\section{Introduction and Background}

As a part of Guangdong University of Business Studies (GUBS), Tourism School was founded in 1986, offering both undergraduate and graduate programs. With an enrolment of nearly 1,000 full-time degree candidates and 38 teachers, the School is sub-divided into three departments: International Tourism Department, Hospitality Management Department and MICE Management Department.

Since GUBS adopted the Blackboard System in 2005, Tourism School has cultivated one web-based course and 47 webenhanced courses, with over six thousand registered users accumulatively.

\section{Literature Review}

Since the commercialization of the Internet, Internet technologies have had profound impacts on learning industry. More and more traditional institutions of higher education, universities and colleges, have realize the potential impact of these technologies, and many of them are now beginning to develop and deliver web-based courses (McCormick, 2000). Researchers have claimed that "nothing will protect the business school from being swept into the current of technologically driven

${ }^{1}$ Data Resource: iResearch China Online Education Research Report (20082009). change” (Ives and Jarvenpaa, 1996: p. 39; Lenzner and Johnson, 1997).

About the web applications in tourism higher education, a review of literature was conducted to identify the problems and issues most often encountered.

A lot of researches have been done to prove the effectiveness of web-based courses compared to traditional classroom education (Selim, 2003; Martins \& Kellermanns, 2004; Ong, Lai, \& Wang, 2004; Pituch \& Lee, 2006). Recent research suggests that technology-mediated learning environments may improve students' achievement (Alavi, 1994; Hiltz 1995; Maki et al., 2000; Schutte, 1997; Wetzel, 1994), their attitudes toward learning (Schutte, 1997), and their evaluation of the learning experience (Alavi, 1994; Hiltz, 1995). Technology may also help to increase teacher/student interaction (Cradler, 1997; Hiltz, 1995; Schutte, 1997), and to make learning more student-centered (Cradler, 1997). As the momentum of the change by which academic practice is defined and implemented (Atton, 1996) is probably based on the new educational space created by local and global information networks (Fowell \& Levy, 1995).

The second hot issue is "instructor". It is a great challenge to find and train teachers to accommodate the new technologies (Pietras, 1995). Also some scholars study the impact of instructors' behaviors on web-based learning (Arbaugh, 2001; Saunders, 2002).

The third most concerned issue is the evaluation of the effectiveness of online education. In his paper Web-Based Virtual Learning Environments: A Research Framework and A Preliminary Assessment to Effectiveness in Basic IT Skills Training, Gabriele Piccoli suggested an assessment framework of "performance, self-efficacy and satisfaction”. (2001) Later, the concept of TOM (Total Quality Management) was adopted in the evaluation (Pan, 2012).

The fourth most prevalent issue to emerge focused on the use 
of intellectual property. The Copyright Law in China was established to provide special provisions for the education environment. In 2000, the people' s supreme court enacted Several Issues Concerning the Laws Applicable to the Trial of Copyright Disputes Involving Computer Networks Interpretations (\#11, Revised, 2006), which offers more specific regulations to the rights of the writers, the infringement, rational use, loss compensation of the digital works under the web circumstances. Since the rapid advancement in technology for online education occurred after the copyright law, it is not altogether clear how the law applies, hence instructors still worry about their online lectures being duplicated and infinitum.

\section{The Dilemma of Chinese Mainland Tourism Higher Education}

In Chinese mainland, the tourism higher education is faced with a dilemma: focus on theoretical knowledge, it'll end up with graduates' incompetency in career development, since tourism management is a very application-oriented discipline; focus on practical skill-trainings instead, it can hardly differentiate itself from tourism vocational education. A compromise can be reached by focusing on both, but there is only little room to squeeze in-with nearly 50 credits required for common courses, there are only 100 credits for specialized knowledge and skill trainings.

The implication of online education may be a feasible solution to this dilemma. There are two levels for its applications: CAI (computer aided instruction) and VLE (virtual learning environment), which enable individual learners to access the materials independently, with different material displays. But the VLE concept is broader than CAI and adds the communication dimension to a previously individualized learning experience. VLEs can foster communities of learners and encourage electronic interaction and discussion (Wilson, 1996). In Tourism School of GUBS, most of courses have applied CAI and some courses have applied VLE, which greatly extends and enriches the curriculums, and finally plays an important role in its ap- plications for Tourism Master Degree Programs (2005) and Provincial Key Specialties (2007).

\section{Some Approaches to Wave Web in Tourism Higher Education}

Instructors will find many ways to use the Web in tourism higher education. If appropriate computer and projection facilities are available, Web materials can be presented in class or laboratory settings. We'll describe some examples of the applications as follows.

\section{Assign Students to Visit Websites Chosen by the Instructor}

The simplest way to add Internet materials to biology teaching is to find useful websites and assign students the task of visiting them. A common practice is to assign students to do a report about what's new in the industry or research field. Take the course "Exhibition Management" for example, the following types of websites are recommended as displayed in Table 1.

\section{Assign Students to Search the Web for Specific Tasks}

Nobody can deny the abundance and variety of web resources. However, when the students are assigned to search the web for specific information, many of them may be frustrated due to the lack of training in search techniques or in evaluation of relevance and quality. So the instructors should design interesting exercises to inspire students, with proper control and online instruction.

There is an example in the course "Hotel Front Office Management”. We made a two-group experimental design. For Group A, traditional classroom instruction (for 1 hour) was applied to explain the reservation procedures, key info in reservation form and some technical terms about reservation. For Group B, we asked them to visit some well-known booking websites to find their most favorite hotel in Zone 13 of Paris,

Table 1.

Selected web pages for "exhibition management".

\begin{tabular}{|c|c|}
\hline Category & Websites \\
\hline Exhibition Databases & $\begin{array}{l}\text { http://www.expodatabase.com } \\
\text { http://www.expoabc.com } \\
\text { http://www.expopromoter.com } \\
\text { http://www.bvents.com }\end{array}$ \\
\hline Associations Related with the Exhibition Industry & $\begin{array}{l}\text { - http://www.ufi.org/ (UFI, Union of International Fairs) } \\
\text { - www.edpa.com (Exhibit Design \& Production Association) } \\
\text { - } \text { www.eaca.com (Exhibitor Appointed Contractor Association) } \\
\text {.. }\end{array}$ \\
\hline Organizations for Exhibition Research & $\begin{array}{l}\text { - http://acced-i.colostate.edu/ (Association of Conference and Events Directors International) } \\
\text {-. } \quad \text { www.ceir.org (Center for Exhibition Industry Research) } \\
\text {.. }\end{array}$ \\
\hline Certificates \& Trainings & $\begin{array}{l}\text { - http://www.iaee.com/cem/ (for CEM, Certified in Exhibition Management ) } \\
\text {... }\end{array}$ \\
\hline Publications & $\begin{array}{l}\text { - http://www.expoweb.com (EXPO Magazine) } \\
\text {-.. http://www.tandfonline.com/toc/wzce20/current (Journal of Convention \& Exhibition Management) }\end{array}$ \\
\hline
\end{tabular}


with a budget of 80 euro per room per night (for $30 \mathrm{~min}$ ); and later, we asked them to present their options (6 min) and discuss about reservation procedures (7 $\mathrm{min})$, key info in reservation form (7 min), followed by a quiz of technical terms about reservation (10 $\mathrm{min})$. Although only slight difference could be observed in a test right after the instruction for these two groups, another test 3 months later indicated that Group B had greater outcome- the average mark was 8.42 points over the comparison group.

\section{Creating the Instructor's Own Course Material Database}

Take "Development and Management of Tourism Resources" for example. The course material database is designed as displayed in Table 2.

\section{Other Applications Offered by Blackboard System}

The Blackboard System also offers some tools to facilitate teaching, such as Instructor's Lecture Notes, Announcement Page, Discussion Room, Quizzes/Exams, and Excellent Student Work, etc.

\section{Surveys on Waving Web in Tourism Higher Education-Based on surveys}

We designed surveys on the students' reaction and KSFs (key successful factors) for online implementation of tourism higher education.

\section{Sample Profile}

The anonymous questionnaire was given to 748 students (three graders in Tourism School of GUBS), and got 674 responses (response rate $90.11 \%$ ). The sample profile is shown in Table 3.

\section{Students' Reactions to the Web-Enhanced Course}

The investigators surveyed students before the midterm and before the final exam. The result is displayed in Figure 1. The test-retest reliability coefficient is greater than 0.85 , quite satisfactory.

\section{KSFs for Online Implementation}

The investigator firstly initiated in-depth interviews (with open options) to decide the factors, and then asked all students to give their percentage weight (on importance) and score the performance of Tourism School in the survey. The outcome (mean) is displayed in Table 4.

Here "Course Development" means the attractiveness of course, without consideration of online or traditional way of instruction. This factor ranks first (38.54\%) in the five KSFs, which indicates the performance of online education highly depends on the quality of course development.

“Technology Support” is also important (27.63\%), which can be represented by quantified indexes such as invested amount, Internet connection speed, etc. The School's performance was not very good (43.57 pints out of 100 points), which indicates

Table 3.

Sample Profile of the Survey.

\begin{tabular}{cccc}
\hline Cohort & Male & Female & Subtotal \\
\hline Y2009 & 103 & 112 & 215 \\
Y2010 & 107 & 117 & 224 \\
Y2011 & 117 & 118 & 235 \\
Subtotal & 327 & 347 & $\mathbf{6 7 4}$ \\
\hline
\end{tabular}

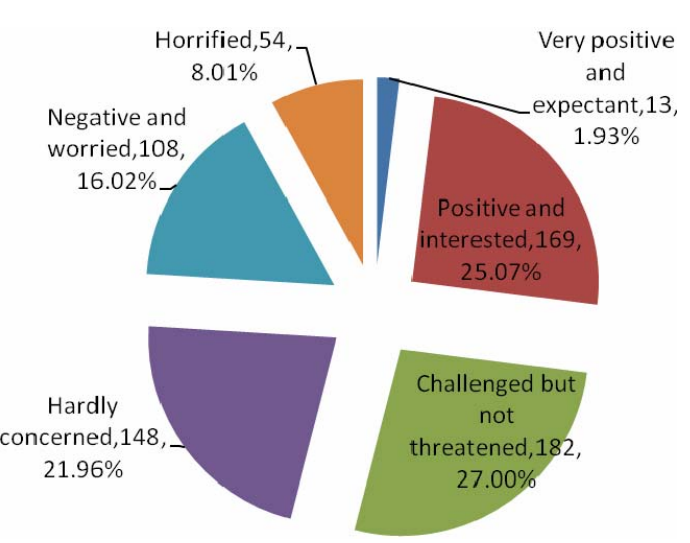

Figure 1.

Students' reactions to the web-based course.

Table 2.

Course material database for “development and management of tourism resources”.

\begin{tabular}{|c|c|c|}
\hline & Category & Remarks \\
\hline Tourism resources ${ }^{2}$ & $\begin{array}{l}\text { A. Geologic landscape } \\
\text { B. Water scene } \\
\text { C. Biology } \\
\text { D. Astronomical phenomena \& climate } \\
\text { E. Historic heritage } \\
\text { F. Architecture \& facilities } \\
\text { G. Tourist Goods } \\
\text { H. Socio-cultural Activities }\end{array}$ & $\begin{array}{l}\text { Pictures, videos and PPT of various tourism resources, } \\
\text { with a total size of over } 3.5 \mathrm{~GB} \text {. }\end{array}$ \\
\hline Case study in development & \multicolumn{2}{|c|}{ e.g. Tourism planning of Qingxin County in Guang Dong (written by the instructor) } \\
\hline Case study in management & \multicolumn{2}{|c|}{ e.g. Experience and lesson in the management of Lechang Eco-tourism Attraction (written by the instructor) } \\
\hline Professional literature & Over 200 articles & \\
\hline
\end{tabular}

${ }^{2}$ The classification of tourism resources is made according to Classification, Investigation and Evaluation of Tourism Resources (GB/T 189722003). 
Table 4.

A survey on KSFs of online implementation.

\begin{tabular}{lccc}
\hline KSF & Percentage Weights of Importance & Performance of Tourism School & Weighted Scores \\
\hline Course Development & $38.54 \%$ & 82.66 & 31.86 \\
Technology Support & $27.63 \%$ & 43.57 & 12.04 \\
Instructor Accessibility & $20.08 \%$ & 63.08 & 12.67 \\
Instructor Preparation & $8.43 \%$ & 77.56 & 6.54 \\
Course Monitoring & $5.32 \%$ & 42.08 & 2.24 \\
Total & $100 \%$ & - & $\mathbf{6 5 . 3 4}$ \\
\hline
\end{tabular}

that there is still much room for improvement. For instance, the Internet connection is rather unstable, and the speed is under 1 $\mathrm{M}$, too slow to download large files.

The third most important factor is "Instructor Accessibility" (20.08\%), which indicates teachers may have to devote more time, including late evenings and weekends, to interacting with students. Actually, online education may demand more working hours, since the teachers are supposed to check the system now and then, reply students' questions and so on. These working hours are usually ignored by the School administrative office.

"Instructor Preparation" means "how well are the instructors trained and prepared", which may also be represented by quantified indexes such as orientation programs offered to teachers, compensation for each web-based or web-enhanced course, teachers' scores in Internet knowledge and skills tests, etc. It is worthwhile to note that many teachers are concerned that once online their lectures could be duplicated ad infinitum, which greatly diminish their enthusiasm in course development. The orientation program and follow-up technical support may reduce such worry though.

“Course Monitoring” means teachers' control and evaluation on students' performance all through the web-based or webenhanced courses, which are also concerned by the interviewees $(5.32 \%)$; the poor score (42.08 pints out of 100 points) of the School indicates that the monitoring system should be improved.

More and more faculty is using Web to supplement and enrich course content. Hundreds of universities are launching big programs and urging faculty to establish their courses on the Web and provide resources to support this requirement. However, no matter what evolutions may occur in forms and channels of knowledge transmission, the faculty remains the critical link in such programs; without their commitment, no programs can achieve objectives despite advanced media of knowledge transmission.

\section{REFERENCES}

Alavi, M. (1994). Computer-mediated collaborative learning: An empirical evaluation. MIS Quarterly, 18, 159-174.

Alavi, M., Wheeler, B. C., \& Vlacich, J. S. (1995). Using IT to reengineer business education: An exploratory investigation of col- laborative telelearning. MIS Quarterly, 19, 293-312.

Ahmad, R., \& Piccoli, G. (1998). Virtual learning environments: An information technology basic skills course on the Web. Proceedings of the 4th American Conference on Information Systems, Baltimore, 14-16.

Bailey, E. K., \& Cotlar, M. (1994). Teaching via the Internet. Communication Education, 43, 184-193. doi:10.1080/03634529409378975

Clark, R. E. (1994). Media will never influence learning. Educational Technology Research and Development, 42, 21-29.

Cooper, L. W. (2001). A comparison of online and traditional computer applications classes. Journal of Industrial Technology, 28, 52-58.

Lander, S. E., Corkill, D. D., \& Staley, S. M. (1996). Designing integrated engineering environments: Blackboard-based integration of design and analysis tools. Concurrent Engineering, 4, 59-71.

Lieblein, E. (2000). Critical factors for successful delivery of online programs. Internet and Higher Education, 3, 161-174. doi:10.1016/S1096-7516(01)00036-7

Pan, Y. L. et al. (2012). A study on the paradigms of quality management in China's distance education. Fudan Education Forum, 10 76-81.

Piccoli, G., Ahmad, R., \& Ives, B. (2001). Web-based virtual learning environments: A research framework and a preliminary assessment of effectiveness in basic IT skills training. MIS Quarterly, 25, 401426. doi:10.2307/3250989 